\title{
THE RELATIONSHIP BETWEEN KNOWLEDGE, BRAND IMAGE AND CUSTOMER BEHAVIOR OF CUSTOMERS DECISION IN CHOOSING SAVINGS PRODUCTS
}

\author{
Zulfi Amalia Putra', Rini Safitri ${ }^{2}$ \\ 1,2 Faculty of Economics, State Islamic University of Maulana Malik Ibrahim Malang \\ Gajayana Street No. 50, Dinoyo, Malang, East Java, 65144, Indonesian
}

$\triangle$ Corresponding Author:

Nama Penulis: Rini Safitri

E-mail: rini.safitri@uin-malang.ac.id

\section{Abstract}

This study aims to determine the effect of knowledge, brand image and customer behavior on customer decision in choosing savings products. Some of previous studies stated that variables which influence customer decisions are knowledge, brand image and customer behavior. However, there is a gap in these conclusions, as some studies suggest that knowledge does not affect customer decisions. Thus, it is important to undertake another research regarding such topic. There are 99 respondents chosen as samples in this study. Collected data were analyzed using SPSS. Results indicated that brand image and customer behavior had a positive and significant influence on customer decisions, while knowledge had no significant effect on customer decisions.

Keywords: Knowledge; Brand Image; Customer Behaviour; Customer Decision

\begin{abstract}
Abstrak
Penelitian ini bertujuan untuk mengetahui pengaruh pengetahuan, citra merek dan perilaku konsumen terhadap keputusan konsumen dalam memilih produk tabungan. Beberapa penelitian sebelumnya menyatakan bahwa variabel yang mempengaruhi keputusan konsumen adalah pengetahuan, citra merek dan perilaku konsumen. Namun, ada celah dalam kesimpulan ini, karena beberapa penelitian menunjukkan bahwa pengetahuan tidak memengaruhi keputusan pelanggan. Oleh karena itu, penting untuk melakukan penelitian lain terkait topik tersebut. Sampel dalam penelitian ini sebanyak 99 responden. Data yang terkumpul dianalisis menggunakan SPSS. Hasil penelitian menunjukkan bahwa citra merek dan perilaku pelanggan berpengaruh positif dan signifikan terhadap keputusan pelanggan, sedangkan pengetahuan tidak berpengaruh signifikan terhadap keputusan pelanggan.
\end{abstract}

Kata kunci: Pengetahuan; Citra Merk; Perilaku Pelanggan; Keputusan Pelanggan 


\section{INTRODUCTION}

Sharia bank have a unique system compared to conventional ones in term of acquiring profit. Abiding the principle of Sharia, they used profit sharing to gain profit (Inggrid, 2010), while conventional banks used interest (Kurnia et al., 2017). These sharia banks have significant growth in Indonesia. However, this does not mean a simultaneous growth in people's financial well-being, especially those from below the line of poverty. In order to resolve this issue, the goverment decided that establishment of any financial insititutions in one region must only serve that particular area, such as Bank Perkreditan Rakyat Syariah (BPRS) (Burhanuddin, 2010).

One example of BPRS is PT. Bank Perkreditan Rakyat (BPR) Syariah Lantabur Tebuireng Jombang, which is a micro, sharia-oriented financial institution located in Jombang City. This BPRS was regarded as "very good" by Infobank for 7 long years. It is also one of 63 BPRS in Indonesia which achieved "Infobank Sharia Awards 2018" with its 250 billion Rupiah asset. It is also one of many financial institution in Jombang who apply sharia principles in its business (Shariannews.com, 2018).

Every financial institution like sharia banks have many services offered to the customer. According to Aminah et al. (2015) services are a product which created to bring benefit to those who use it. BPRS Lantabur Tebuireng also create such services, while still abide by sharia principles. When customers have to choose between services and financial institution, their knowledge become a major influence.

Knowledge is an information owned by customer regarding a particular product, services, and experiences Sunyoto (2013), which can be obtained through media Kautsar (2014) or by experiencing such services themselves (Anni, 2014). Yuliawan (2011) stated that knowledge regarding services or product is focused on how it can bring benefit and satisfaction to the customer. This is an opportunity for BPRS Lantabur Tebuireng to provide socialization towards educational institution, mainly teachers and students, about how their services can bring benefits, such as Qolam Savings program which dedicated to student only. This can lead to rapid growth in sharia bank, as well as increase the amount of customer they have.

Table 1, it is evident that customers of BPRS Lantabur Tebuireng reach the number of 23,510 people, from all four services offered. To better understand customer satisfaction regaring this services, it is important to observe what kind of behavior can lead to purchase. BPRS Lantabur Tebuierng need to utilize these informations so they can offer more suitable and beneficial services to customer, which is also unique compared to its competitors. 
Table 1. Number of Customers PT. BPRS Lantabur Tebuireng Jombang

\begin{tabular}{lr}
\multicolumn{1}{c}{ Savings Type } & Number of Customers \\
\hline Tadhabbur Savings & 16,018 \\
\hline Qolam Savings & 6,306 \\
\hline Hijrah Savings & 1,153 \\
\hline Taqarrub Savings & 33 \\
\hline \multicolumn{1}{c}{ Total } & $\mathbf{2 3 , 5 1 0}$ \\
\hline
\end{tabular}

Sourse : Data from BPRS Lantabur Tebuireng Jombang 2019

Customers decision making can be affected by their experience and how well they understand the problem that is currently being faced (Daft, 2010). From the decision making process, customer will observe all available alternatives for them, to find which services is the best. A service specifically offered to particular customer can also affect the decision making process. Student savings program from BPRS Lantabur Tebuireng is one of such services. Brand image is also an important factor in this scenario. (Kotler \& Keller, 2015) explained that brand image is how well a brand perceived and remembered by customers. Customers of BPRS Lantabur Tebuireng perceived that services given by the company is credible, satisfactory, and beneficial (Ummah \& Sastika, 2016). This perception about offered services is very beneficial for the company, as it create a good brand image, and will be more likely to be chosen by customers among other services they know.

Study from Hastuti (2018) and Ratnasari et al. (2014) indicated that brand image has positive and significant effect towards customers decision. While Shintia et al. (2019) stated that there are no simultaneous effect on brand image, which consist of creator image, product image, and user image, towards customers decision. Those findings are the main reason why this topic need to be readdressed, because there is a research gap between past studies.

\section{LITERATURE REVIEW}

\section{Customers Knowledge}

Knowledge is an understanding regarding particular topic Setyosari (2013) or an information that can be remembered Sopiah (2013) about the benefit of a product Mulyana et al. (2014). Mowen \& Minor (2002) stated that customers knowledge will increase if experience or information about chosen services can be utilized and bring benefit to them. There are few factors that can affect this knowledge, such as education, mass media, social economy/income, social connection, and experience. The Hypothesis showed by Figure 1.

H1: Customers knowledge affects customers decision 


\section{Brand Image}

Brand Image is a name, writing, or symbol in a product that make it unique compared to the others Tjiptono (2014) which can promote its uniqueness to customers so it can be remembered more easily. Research by Ferrinadewi (2011) showed that brand image is how well a product perceived by customers to the point where they can associate themselves with it. Accoring to Wahyudi (2012), brand image can be developed through customers experience about products and services offered, where it can be advertised as such to another customers to develop the desired brand image. $\mathrm{H} 2$ : Brand image affects customers decision

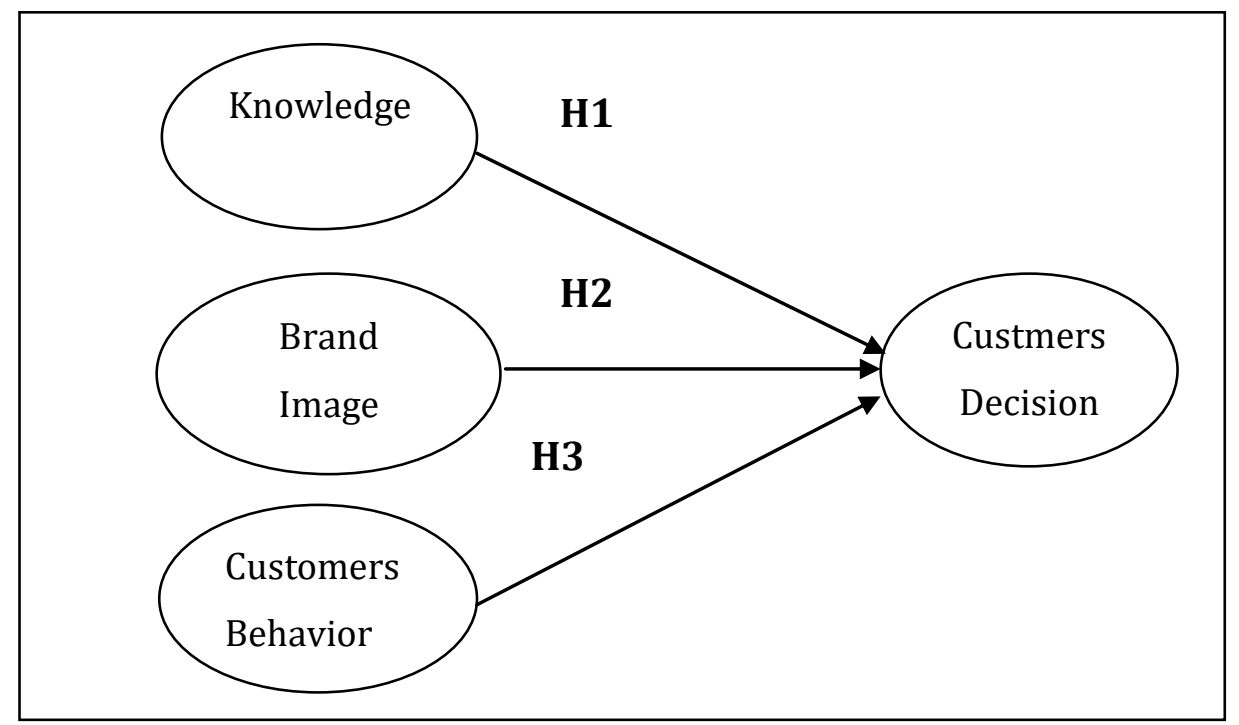

Figure 1. Developed from previous research Source: Data by Researchers (2020)

\section{Customers Behavior}

According to Engel et al. (2010), customers behavior is an action by customer to obtain goods or service they want. This behaviour begin from buying, where customer will observe, use, and spent their product (Zubaidi, 2011). Because of this, customers behavior can be considered as an act to obtain, buy, and consume a product (Nitisusatro, 2013; Winardi, 2015). Some factors can influence this behaviour, such as social economy, products offered, price, advertisement, and marketing.

H3: Customers behaviour affects customers decision

\section{METHOD}

This research was performed in BPRS Lantabur Tebuireng in Jombang City. Random sampling was used to obtain samples, so all member of population have equal chance to become a sample (Sugiyono, 2013). The amoun of samples needed was determined using Slovin formula, where 99 
respondents were chosen as samples. Data were collected using questionnaire, which later processed using SPSS 21 to analyze the proposed hypotheses in this research. The test effect using multiple linear regression.

\section{RESULT AND DISCUSSION}

\section{Respondent's Characteristics}

There are three main characteristics of respondents, namely gender, age, and education. Based on gender, $62.6 \%$ of respondents are female (62 people). From age perspective, all respondents' ( 99 people) age ranged from 16 to 20 years old. All of them also have completed their senior high school education, which is appropriate considering that they are expected to manage their own allowance and savings.

\section{Validity and Reliability Test}

Validity can be measured by comparing correlation value between each indicators in t-table. Validity test indicated that all items used in measurement, that is knowledge (X1), brand image (X2), customers behavior (X3), and customers decision (Y), are valid. It is also evident that with $r$ of 0.1975 , it can be concluded that all indicators used in every variables are valid. While croncbach alpha from knowledge, brand image, customers behavior, and customers decision are higher than 0.60 , which shows that all variables are reliable.

\section{Classical Assumption Test}

Based on classical assumption test, it is clear that there are no heteroscedasticity. The unstandardized residual is normal distribution. The tolerance higher than 0.10 and VIF value for all independent variables less than 10 , it is also evident that there are no multicollinearity.

\section{Multiple Linear Regression}

Significance level show in Table 2, is knowledge of 0.561 (higher than 0.05), which means that this variable does not have a significant effect toward customers decision. This finding does not allign with the proposed hypothesis. It is, however, supports findings from past research by (Hanzaee \& Ghafelehbashi, 2012; Tanuwidjaya \& Hikmah, 2020), which stated that customers involvement is more important than customers knowledge. This happened because without knowledge about the product, customers will buy it as long it fulfill their needs. This condition indicates that customers will need more products according to their needs without knowing the knowledge of the product. 
Table 2. Partial Test (T)

\begin{tabular}{cccccc}
\hline & \multicolumn{2}{c}{$\begin{array}{c}\text { Unstandardized } \\
\text { Coefficients }\end{array}$} & $\begin{array}{c}\text { Standardized } \\
\text { Coefficients }\end{array}$ & & \\
\cline { 2 - 4 } Model & B & $\begin{array}{c}\text { Std. } \\
\text { Error }\end{array}$ & Beta & T & Sig. \\
\hline (Constant) & 10.325 & 4.009 & - & 2.576 & 0.012 \\
\hline Knowledge & 0.078 & 0.133 & 0.045 & 0.584 & 0.561 \\
\hline Brand Image & 1.168 & 0.134 & 0.661 & 8.743 & 0.000 \\
\hline $\begin{array}{c}\text { Customers } \\
\text { Behavior }\end{array}$ & 0.077 & 0.038 & 0.154 & 2.026 & 0.046 \\
\hline
\end{tabular}

Source: Data by Researchers (2020)

Brand image has significance level of 0.00 (less than 0.05), which means that this variable has significant impact towars customers decision. In this case, brand image of BPRS Lantabur Tebuireng will have a significant role in affecting customers decision to join their savings program. Brand image consists of three indicators, namely value, quality, and awareness. Based on the result, it is shown that brand image has a significant and positive impact on customers behavior. This finding fits with the proposed hypothesis. If the company is able to maintain a good image to their customers, then they will more likely to be chosen as the most adequate financial service provider. The results of this study are also in line with (Ratnasari et al., 2014; Sondakh, 2014; Subagiyo, 2016) who found that brand image has a positive and significant effect on customer decisions. This is because with a good brand image, there will be positive feelings when buying and using these products. Moreover, the image that is embedded in a product is good, so the customer will use the product again, and vice versa if the image embedded in a product is bad, the customer will not use or choose the product again. Seeing the importance of brand image in the company, the company must also build a good brand image.

Customers behavior has significance level of 0.046 (less than 0.05), which indicates that there is a correlation between behavior and decision to become customer of BPRS Lantabur Tebuireng. In this research, customers behavior consist of five indicators, that is social economy, product, promotion, marketing, and price. This means that the company need to pay close attention to customers behavior, as it indicates which customer is going to buy their products. The results of this study are in line with research which explains that there are factors that can influence customer behavior in customer decisions, namely cultural, social, personal and psychological factors. From these factors, it aims to determine consumer behavior that can affect customer satisfaction or dissatisfaction when buying a product. This explains that looking at the factors of customer behavior is very important in making customer decisions. 
Table 3. Simultaneous (F)

\begin{tabular}{lrrrrr}
\hline Model & $\begin{array}{c}\text { Sum of } \\
\text { Squares }\end{array}$ & Df & $\begin{array}{c}\text { Mean } \\
\text { Square }\end{array}$ & F & Sig. \\
\hline Regression & 321.123 & 3 & 107.041 & 27.395 & 0.000 \\
\hline Residual & 371.200 & 95 & 3.907 & & \\
\hline Total & 692.323 & 98 & & & \\
\hline R Square & 0.464 & & & & \\
\hline
\end{tabular}

Source : Output from SPSS21, 2020

Based on Table 3, it is shown that F value is 27.395 with significance level of 0.000 . These results indicate that knowledge (X1), brand image (X2), and customers behavior (X3) are affecting customers decision (Y) simultaneously, which means that the regression model can be utilized to predict all three independent variables mentioned. Based on Table 3, R Square is 0.464 , which means that all three independent variables can explain $46.4 \%$ of customers decision. While the remaining $53.6 \%$ can be explained by another variable not included in this research. The results of this study are also in line with (Aisha, 2017; Hakim, 2016; Tajudin \& Mulazid, 2017; Zulfikar \& Hamdani, 2017) who found that knowledge, brand image and customer behavior are affecting customers decision.

\section{CONCLUSION}

Knowledge does not significantly affect customers decision in choosing student savings program offered by BPRS Lantabur Tebuireng. This means that customers knowledge about savings program does not play any role in decision making process. In reality, customers do not really compare one product with another, thus knowledge is not the essential part in choosing services. While brand images and customers behavior have significant impact on customers decision in choosing student savings program in BPRS Lantabur Tebuireng. Which means that it is important for BPRS Lantabur Tebuireng to maintain a good image to their customers, as well as pay close attention to their behavior, because it can indicate which person will eventually become their customer.

BPRS Lantabur Tebuireng have to make sure that they develop a good image for themselves, which can be achieved with good service and beneficial services. This can contribute to developing trust within the customer, which potentially spread positive word-of-mouth about company's image. For future research, it is advised to broaden this topic by including respondents from different education level. 


\section{REFERENCES}

Aminah, S., Murniati, A., \& Nasir, U. (2015). Implementasi Manajemen. Berbaasis Sekolah dalam Meningkatkan Mutu Pendidikan Pada MTsN Kota. Jurnal Administrasi Pendidikan Pascasarjana Universitas Syiah Kuala, 3(2), 1-11.

Anni. (2014). In ANNI Report on the Performance and Establishment of National Human Rights Institutions, ed. Forum Asia. 58-75.

Aisha, N. (2017). Analisis Pengaruh Kualitas Produk dan Kualitas Pelayanan terhadap Citra Merek PT Bank SUMUT pada Nasabah PT Bank SUMUT Cabang Medan Iskandar Muda. Jurnal Samudra Ekonomi Bisnis, 8(2), 160-172. https://doi.org/10.33059/jseb.v8i2

Burhanuddin. (2010). Aspek Hukum Lembaga Keuangan Syariah. Graha Ilmu.

Daft, R. L. (2010). Era Baru Manajemen (9 ed.). Jakarta: Salemba Empat.

Engel, Featherstone, M., \& Aksara. (2010). Perilaku Konsumen. Edisi Keenam, jilid 1. Jakarta: Binarupa Aksara.

Ferrinadewi, E. (2011). Merek dan Psikologi Konsumen. Yogyakarta: Graha Ilmu.

Hanzaee, K. H., \& Ghafelehbashi, S. (2012). The role of product involvement, knowledge, and perceptions in consumer purchase behavior of counterfeits: Perspective Islamic country. Journal of Basic and Applied Scientific research, 2(1). 418-425.

Hakim, L. (2016). Analisis Pengaruh Brand Image Terhadap Keputusan Konsumen Pada BPR Sejahtera Batam. Jurnal Dimensi, 1(1), 1-15. https://doi.org/10.33373/dms.v5i1.19

Hastuti, N. B. H., Rommy, M. A. S. N., \& Nur, A. R. Y. N. (2018). “Effect of Brand Image and Price Perception on Purchase Decision". IOSR Journal of Business and Management, 20(8), 76-81.

https://doi.org/10.9790/487X-2008027681

Inggrid, T. (2010). Buku pintar asuransi: Harapan terakhir yang tak terduga.

Kautsar, A. (2014). Analisis Pengaruh Firm Size, DER, Dan Sales Growth Terhadap Dividend Payout Ratio Dengan ROE Sebagai Variabel Intervening Pada Perusahaan Non Keuangan yang Listed Di Bei Tahun 2009-2011. Jurnal Bisnis Strategi, 23(2), 1-13. https://doi.org/10.14710/jbs.23.2.1-13

Kotler, P., \& Keller, K. (2015). Marketing Management 14 Edition. Pearson.

Kurnia, R. A. E., Sawarjuwono, T., \& Herianingrum, S. (2017). Manajemen risiko pembiayaan untuk mengantisipasi kondisi financial distress pada bank syariah. Journal of Islamic Economics Lariba, 3(2), 51-64. https://doi.org/10.20885/jielariba.vol3.iss2.art1

Mowen, J. C., \& Minor. (2002). Perilaku Konsumen. Jakarta: Penerbit Erlangga.

Mulyana, A., Sumarwan, U., \& Maulana, A. (2014). Model Perilaku Pembelian Pakaian Kota Bandung. Jurnal Bisnis dan Manajemen, 14(1), 14-19.

Nitisusatro, M. (2013). Perilaku Konsumen Dalam Prespektif Kewirausahaan. Bandung: CV Alfabeta. 
Ratnasari, M. D., Seno, A. H. D., \& Listyorini, S. (2014). Pengaruh citra merek dan kualitas produk terhadap keputusan pembelian Blackberry (study kasus mahasiswa S1 FISIP Universitas Diponegoro Semarang. Diponegoro journal of social and politic, 1-6.

Setyosari, P. (2013). Metode Penelitian Pendidikan dan Pengembangan. Jakarta: Kencana Prenadamedia Group.

Shariannews.com. (2018). Garis Lurus Zakat. Shariannews.com/posts/garislurus-zakat

Shintia, N., Nuryadin, M. T., \& Anwar, W. (2019). Pengaruh Brand Image Terhadap Keputusan Nasabah Memilih Produk BNI Taplus pada PT Bank Negara Indonesia (Persero) Tbk Kantor Wilayah Banjarmasin. Inovbiz: Jurnal Inovasi Bisnis, 7(1), 15-19. https://doi.org/15. 10.35314/inovbiz.v7i1.947

Sondakh, C. (2014). Kualitas Layanan, Citra Merek Dan Pengaruhnya Terhadap Kepuasan Nasabah Dan Loyalitas Nasabah Tabungan (Studi Pada Nasabah Taplus Bni Cabang Manado). Jurnal Riset Bisnis Dan Manajemen, 3(1), 19-32

Subagiyo, R. (2016). Pengaruh Brand Image Terhadap Keputusan Nasabah Dalam Memilih Pembiayaan di BMT Sahara Tulungagung. Malia: Jurnal Ekonomi Islam, 8(1), 1-20. https://doi.org/10.35891/ml.v8i1.360

Sugiyono. (2013). Metode Penelitian Bisnis. CV Alfabeta. Bandung.

Sunyoto, D. (2013). Perilaku Konsumen: Panduan Riset Sederhana untuk Mengenali Konsumen. CAPS.

Tanuwidjaya, T., \& Hikmah. (2020). Effect Of Brand Image, Advertising And Perception Of Decision Of Customers Saving On PT BPR Dana Fanindo. Jurnal Emba, 8(1), 1967-1976.

https://doi.org/10.35794/emba.v8i1.28047

Tajudin, M. H., \& Mulazid, A.S. (2017). Pengaruh Promosi, Kepercayaan Dan Kesadaran Merek Terhadap Keputusan Nasabah Menggunakan Produk Tabungan Haji (Mabrur) Bank Syariah Mandiri Kcp. Sawangan Kota Depok. Islamiconomic: Jurnal Ekonomi Islam, 8(1), 19-46. https://doi.org/10.32678/ijei.v8i1.64

Tjiptono, F. (2014). Pemasaran Jasa: Prinsip, Penerapan, dan Penelitian. Yogyakarta: CV Andi Offset.

Ummah, M., \& Sastika, W. (2016). Pengaruh Brand Image Terhadap Keputusan Pembelian Cafe Lawang Wangi Creative Space (Studi Pada Masyarakat Bandung 2016). e-Proceeding of Applied Science, 2(2).

Wahyudi. (2012). Manajemen Sumber Daya Manusia. Wahyudi. (2012). Manajemen Sumber Daya Manusia. Sulita, Bandung: Sulita.

Winardi. (2015). Manajemen Prilaku Organisasi, Edisi Revisi. Jakarta: Prenada Media Group.

Yuliawan, E. (2011). Pengaruh Pengetahuan Konsumen Mengenai Perbankan Syariah Terhadap Keputusan Menjadi Nasabah pada PT. Bank Syariah Cabang Bandung. Jurnal Wira Ekonomi Mikroskil, 1(01), 21-30. 
Zulfikar \& Hamdani. (2017). Pengaruh Citra Pembuat/Corporate Image, Citra Pemakai/User Image, dan Citra Produk/Product Image Terhadap Loyalitas Nasabah Produk Tabungan Britamapada PT. Bank Rakyat Indonesia Kota Lhokseumawe. Ekonis: Jurnal Ekonomi dan Bisnis, 17(1), 22-31. http://dx.doi.org/10.30811/.V17i1.350

Zubaidi, A. (2011). Analisis faktor-faktor yang mempengaruhi ERC pada perusahaan real estate. Jurnal Akuntansi dan Keuangan, 16(1). 